Research Article

\title{
The Benefits of Cooperative Learning of Language in Different Subject Lessons as Seen by Primary School Pupils: The Case of One Lithuanian City School
}

\author{
Daiva Jakavonytè-Staškuvienè \\ Education Academy, Vytautas Magnus University, Kaunas, Lithuania \\ Correspondence should be addressed to Daiva Jakavonytė-Staškuvienė; daiva.jakavonyte-staskuviene@vdu.lt
}

Received 8 October 2021; Revised 13 November 2021; Accepted 15 November 2021; Published 30 November 2021

Academic Editor: Ehsan Namaziandost

Copyright (C) 2021 Daiva Jakavonyte-Staškuvienè. This is an open access article distributed under the Creative Commons Attribution License, which permits unrestricted use, distribution, and reproduction in any medium, provided the original work is properly cited.

\begin{abstract}
Contemporary educational theory and practice promote the development of subject-specific and generic competences. Cooperative learning is a generic competence whose development is recommended in all subject lessons/activities. The development of fundamental individual values that rely not only on individual achievements but also on empathy and helping others, the ability to listen, mentor, and assist is integral to primary education. Such education is supported by positive inclusion in the process and good-willed communication within the group to achieve a common result. It is through achieving common goals and witnessing the variety of activity approaches that certain activities become a success. The study aimed to include all students in the development process on the basis of cooperative learning and improve each and every student's individual learning of language performance in all subjects. The study is based on 186 first-to-fourth-year students from one major city school, representing a total of 8 classes. After the school-wide activities on cooperative learning, all pupils took part in a questionnaire survey halfway through the school year. The survey used a written questionnaire. The questions in the questionnaire were designed to explore pupils' attitudes towards school and language-related aspects of successful group cooperation. The collected data were analysed using SPSS version 20. The data analysis used a descriptive approach, calculating the answers chosen by the pupils. An analysis of the survey results shows that the majority of pupils in years 1 to 4 think they can work in groups and cooperate because they are willing to listen to others, explain and help others, are not bored, are interested in working together, and are interested in learning new subjects.
\end{abstract}

\section{Introduction}

The framework document "Good School Concept" [1] regulating the curriculum of Lithuanian schools states that the curriculum should be interesting, stimulating, sufficiently broad, and comprehensive, creating challenges, promoting solutions to problems, and developing the competences necessary for modern life, and pupils should be learning through research, experimentation, discovery, invention, creation, communication, and cooperation. Learning through cooperation, solving common problems, creating when the other's views are taken into account and listened to are key competences of particular importance in future life. In the draft of updated Lithuanian Language
Framework Programmes [2], language education stipulates that language "learning involves the integration of subjects because language topics come from different walks of life...Integrated learning of language (Lithuanian, foreign languages) and other subjects is promoted" (p. 1). This means that strategic preconditions for developing linguistic competences in an integrated way by learning other subjects are in place, and this can be done properly through cooperative learning. Furthermore, the recommendations of the European Commission on Teaching and Learning [3] highlight the solution of complex problems while working together, communicating, and cooperating. Person's core values, which focus not only on individual achievements but also on empathy, assistance to others, the ability to listen, 
TABLE 1: Example of the quality of life at school scale (according to [16]).

\begin{tabular}{|c|c|c|}
\hline Satisf & Commitment to work at school & Positive relationship with teachers \\
\hline (i) I like school & $\begin{array}{l}\text { ve working in a class/school so much that I } \\
\text { ant to stop working }\end{array}$ & $\begin{array}{l}\text { (i) I'd like this teacher to teach me next year } \\
\text { as well }\end{array}$ \\
\hline $\begin{array}{l}\text { (ii) Most of the time I do not like } \\
\text { going to school }\end{array}$ & ii) Working in a class is a waste of time & $\begin{array}{l}\text { (ii) The teacher behaves in a way that } \\
\text { "makes" me "love" them }\end{array}$ \\
\hline
\end{tabular}

advise, and help, are developed in an integrated way in primary schools. Regarding primary school pupils' group work, the value of self-identification as a group/class member, which enables quality learning, is emphasised. A child learns in a positive mood if they identify themselves with the classroom/school environment and feel fully fledged members of it. It is important for a pupil to identify themselves with the educational community/group. It is much harder if a child does not see themselves in that space. In this case, learning can be problematic and irrelevant, not only because it is inaccessible but also because it is not even sought at all [4-9]. Research has shown that cooperative learning impacts pupils' social inclusion $[10,11]$.

The foundation of today's primary education is the learner-centered pedagogy. Under the conditions of such education, the teacher is an assistant, a creator of the educational situation (context), who chooses the methods of education, and helps the learner follow an individual learning path. It is important to diagnose the current situation and the pupil's achievements and offer suitable activities and a system of motivation/encouragement that can be covered individually by each learner who would experience learning success as a result [12]. In addition, it is essential that the curriculum is developed according to each pupil, thinking about their contribution and the individual progress made, as this allows the child to take responsibility for their own learning. Such successful education is facilitated by activities where each pupil feels important and significant, and learning poses overwhelming challenges. This type of education is particularly conducive to working in a group, provided that certain roles and responsibilities are shared. In addition, it is important that educators can see each of their pupils according to their abilities and accept each child (whatever their abilities) positively and favourably [13-15]. Cooperative education based on agreements guarantees the success of activities. The educator provides help by commenting on the pupil's actions, advising on how the work can be improved.

\section{Review of Related Studies}

2.1. Theoretical Underpinnings of School Satisfaction. In order for a teacher to be able to create an appropriate learning environment, they should bear in mind several aspects of being at school [16], which are significant for primary school pupils (Table 1).

Florin and Guimard [16] identified pupils who are interested in the work of the school and are satisfied with the school in general. If a pupil responds positively to these aspects, if they share this view, it is highly likely that a positive attitude will also be involved in educational activities, which significantly increases the likelihood of learning. Such an examination of attitudes to school is recommended before or after planned activities in the group. Answers for the educator could help link the student's results to the determination to act actively and make efforts to improve the outcome.

The satisfaction of the school scale [17] distinguishes between the experience gained at school and the feelings experienced by the pupil. The author distinguishes between the following aspects of school life: the relationship between teachers and pupils, the relationship with peers or other people, the importance that pupils attach to school as a place of learning, the experiences/competences acquired, and the interest or motivation to learn (Table 2):

This model helps to find out the pupil's state, the feeling that is crucial for learning success, so it is recommended to discuss it with pupils, especially if they express their negative feelings/opinions in any area. When discussing and talking to a child, assistance measures should be put in place to improve their feelings towards the school.

Liu et al. [18] supplemented the school's life scale with academic knowledge and feelings related to this area.

The needs of the pupils listed in Table 3 are essential and important for the full well-being of the school, on which learning success depends heavily. Educators should, on the basis of these criteria, evaluate/examine the well-being of each pupil and thus choose the methods of education and the system of aid measures. It is important that children feel safe at school that they feel part of the school community because it has a direct impact on learning.

As regards class factors, there are positive links between the academic satisfaction of pupils and the ability to participate in school activities and influence the classroom environment. The same is true when a pupil feels respected and safe and when they have a positive view of their teacher's activities [19] and when there is an atmosphere of mutual assistance and support in the classroom [20]. In a primary school, pupils' motivation and academic achievement improve when classroom activities are optimal and when pupils can complete them with a little effort (with a particular challenge in place), when teachers provide informative feedback that encourages them to continue to act, and when interpersonal competition is restricted and children-to-child relationships are focused on assisting each other. At the same time, the clarity of class rules has a positive effect on pupils' academic satisfaction. The study carried out by Randolph et al. [19] in Finland revealed that primary school pupils 
TABLE 2: Example of the school's quality-of-life scale (according to [17]).

\begin{tabular}{|c|c|c|c|c|}
\hline $\begin{array}{l}\text { Relationship between } \\
\text { teachers and pupils }\end{array}$ & Sense of satisfaction & Social integration & Good experience & General satisfaction \\
\hline $\begin{array}{l}\text { My school is a place } \\
\text { where a teacher: }\end{array}$ & My school is a place where: & My school is a place where: & $\begin{array}{c}\text { My school is a place } \\
\text { where: }\end{array}$ & $\begin{array}{c}\text { My school is a place } \\
\text { where: }\end{array}$ \\
\hline (i) Teaches me patiently & $\begin{array}{l}\text { (i) My work gets me to the } \\
\text { level of learning that satisfies } \\
\text { me }\end{array}$ & $\begin{array}{l}\text { I'm good at getting along } \\
\text { ith other pupils in the class }\end{array}$ & $\begin{array}{l}\text { (i) The work we do is } \\
\text { interesting }\end{array}$ & $\begin{array}{l}\text { (i) I love going every } \\
\text { single day }\end{array}$ \\
\hline (ii) Is honest with me & $\begin{array}{l}\text { (ii) I always/often experience } \\
\text { success }\end{array}$ & \multirow{4}{*}{$\begin{array}{l}\text { (ii) The kids trust me } \\
\text { (iii) I'm popular among } \\
\text { other pupils } \\
\text { (iv) The teachers and } \\
\text { children pay attention to me }\end{array}$} & \multirow{4}{*}{$\begin{array}{l}\text { (ii) I always do a work that } \\
\text { I'm really interested in } \\
\text { (iii) I like what I do in the } \\
\text { classroom }\end{array}$} & \multirow{4}{*}{$\begin{array}{l}\text { (ii) I enjoy the fact } \\
\text { that I'm out there } \\
\text { (iii) I always miss it a } \\
\text { lot } \\
\text { (iv) I like being there }\end{array}$} \\
\hline $\begin{array}{l}\text { (iii) Thinks they can } \\
\text { help me }\end{array}$ & & & & \\
\hline (iv) Listens to what I say & & & & \\
\hline & & & & \\
\hline
\end{tabular}

TABLE 3: Example of the quality-of-life scale for primary school pupils (according to [18]).

\begin{tabular}{|c|c|c|c|c|c|}
\hline Academic learning & School management & $\begin{array}{l}\text { Teacher-student } \\
\text { relationship }\end{array}$ & Achievements & $\begin{array}{l}\text { Relationships with } \\
\text { peers }\end{array}$ & Learning \\
\hline $\begin{array}{l}\text { I have plenty of time } \\
\text { to do homework } \\
\text { assigned by my } \\
\text { teachers }\end{array}$ & $\begin{array}{l}\text { The school asks our opinion } \\
\text { before adopting the rules, } \\
\text { and takes it into } \\
\text { consideration }\end{array}$ & $\begin{array}{l}\text { Teacher(s) help me } \\
\text { when I encounter a } \\
\text { problem }\end{array}$ & $\begin{array}{l}\text { I'm good at } \\
\text { learning }\end{array}$ & $\begin{array}{l}\text { I care about my } \\
\text { classmates, their } \\
\text { opinion }\end{array}$ & $\begin{array}{l}\text { Teachers integrate } \\
\text { games/workshops } \\
\text { into teaching }\end{array}$ \\
\hline $\begin{array}{l}\text { I'm interested in } \\
\text { learning material, it's } \\
\text { interesting to me }\end{array}$ & $\begin{array}{c}\text { Our school environment is } \\
\text { beautiful }\end{array}$ & $\begin{array}{l}\text { Teachers are our } \\
\text { friends }\end{array}$ & $\begin{array}{l}\text { I'm doing a good } \\
\text { job at school }\end{array}$ & $\begin{array}{l}\text { I have friends at } \\
\text { school }\end{array}$ & $\begin{array}{l}\text { The learning load is } \\
\text { moderate, and you } \\
\text { can keep up with it all }\end{array}$ \\
\hline
\end{tabular}

(7-12 years old) feel better in classrooms with up to 20 pupils in size. This indicator is significant because not only are pupils more satisfied with the school and their learning but also when the class is smaller, pupils are given more personal attention from the teacher. On the contrary, according to Florin and Guimard [16], the well-being of pupils in the classroom depends on its climate and the system of creating and maintaining positive relationships and motivating pupils. All of this depends very much on the attitudes of the primary school teacher and their goodwill to build and maintain such relationships. The comparison of the satisfaction with school and motivation to act of primary school teachers and pupils in the United Kingdom [21] and in France [22] revealed that pupils and teachers who study and work in private schools feel much better.

The above-mentioned well-being-at-school scales and other factors related to pupils' motivation are crucial for pupils to work in the group. In the case of cooperative learning, the working group has deeper principles relating to interdependence and accountability, empathy and mutual assistance, and each child's individual contribution to achieving common outcomes.

\subsection{Theoretical Foundations for Successful Cooperative} Learning. Cooperative learning is defined by 5 attributes of successful cooperation in groups where children work to help, advise, and discuss [23-33]:

(i) Positive interdependence in groups is captured when pupils understand that they are all responsible for performing the task that everyone contributes to this common goal and therefore needs to be able to combine their abilities and efforts and be able to agree.

(ii) Stimulating interaction is a willingness and effort to help each other and facilitate the accomplishment of the task. Elements such as listening to each other, consulting, explaining, arguing, and assisting in sharing tools and resources to carry out the task are important. In this area, emphasis is placed on the importance of language skills and the ability to listen and use language tools, such as appropriate words and phrases for support and encouragement, notions related to the content of subjects.

(iii) Individual and mutual responsibility and accountability are closely linked to interdependence. It is captured when each member of a group is willing to do their part of the job but, at the same time, creates the preconditions for others to do their job. After the activity, it is important to appreciate not only the final result of the work but also the individual contribution and the learned content of all activities. It is important that children can also appreciate how they understood and learned the content that other group members were responsible for.

(iv) Cooperative skills relate to a culture of interaction and communication and polite and responsible behaviour in listening to and commenting on ideas of others, expressing opinions, making decisions, and sharing tools, roles, and activities. 
(v) The reflection of the group's work takes place when the following questions are discussed and answered: what have we accomplished, what else should we do, and how can we do it?

Researchers in some countries [34-37] have shown that cooperative learning helps create an environment conducive to higher achievement. It is important that students help each other in cooperative learning to motivate their learning. The classroom environment becomes empathetic and conducive to learning for children of different abilities [38], as it reduces the chances of unpleasant situations and increases learning satisfaction. It is important to teach pupils to work together towards a common goal rather than to compete $[38,39]$, as competition (especially in the primary grades) is counterproductive and reduces pupils' motivation to learn.

In the light of these characteristics of cooperative learning, questions were formulated for pupils, which included individual contributions to group activities in the development of abilities of language and another subject. Due to the limited scope of the article, we will provide pupils' answers from only one group of questions (investigating a pupil's work in a group).

\section{Method}

3.1. The Current Study. The study aims to theoretically and empirically justify the merits of primary school pupils' working in a group when language is taught in cooperation in all subjects.

The objectives of the study are as follows:

(1) To discuss the importance and significance of satisfaction with school for the promotion of primary school pupils' positive attitudes and their motivation to learn.

(2) To explore and analyse the attitudes of primary school pupils towards school, learning, and achievement.

(3) To explore and analyse the views of primary school students on working in a group where language is taught in cooperation in all subjects.

The study was conducted at a primary school in one of the big cities in Lithuania in May 2019. At school, a cooperative learning methodology was implemented for half of the school year (from February 2019 to the end of May). Pupils were encouraged to cooperate, request, and provide assistance, perform their duties, and achieve the overall objective of the group task in different classes. Before planning and organising activities at school, all primary school teachers took part in 24-hour refresher courses to explore and deepen their knowledge of cooperative learning. The study is important and significant from the point of view of innovative didactics. It allows us to investigate how children evaluate their role in group work by explaining how they behave in one way or another. For this reason, the findings of the study are important for educational practice, as they allow for the choice of a method whose value is understood by the pupils themselves. The survey data are also important for teacher training, as the pupils' responses will help to provide insight into which areas are most difficult for children and what should be considered when learning cooperatively.

3.2. Study Method. The survey used a written questionnaire. After half a year of school-wide activities in the field of cooperative learning, all pupils filled in a questionnaire. The survey was carried out through a written questionnaire. This survey aims to explore pupils' attitudes towards cooperative learning and the contribution of pupils themselves when language skills are developed in lessons of all subjects while cooperating in an integrated way [40].

The questions in the questionnaire were designed to explore students' attitudes towards school and languagerelated aspects of successful group cooperation. The study looked at what pupils' attitudes towards the school were (see Figure 1). Provided below is an example of a question about pupils' attitudes towards school (Figure 1).

The choice of answers to the question in Figure 2 allows researchers to see a general trend in what the emotional microclimate of the school is, which determines children's attitude and desire to be part of an educational establishment and to work and learn together. The answers to this question suggest the extent to which children may be inclined to work together, to work in one group with other children in the classroom.

Considering the characteristics of successful group cooperation defined in the concept of cooperative learning, such as children's ability to work with each other by helping and advising each other, discussing, and listening to each other's opinions [23-33], a questionnaire has been developed. These questions were developed by a team of researchers from the DICO + project, one from each country. The author of this article was one of the team members.

The questionnaire included a nine-statement question "How do you work in a group?" The optional answers were given to the pupils on an interval scale, emphasising the intensity of the subject's expression, assessing the essence of the question [40]. The above considerations are important for investigating pupils' attitudes towards their own behaviour in group work. Provided below is an example of the question (Figure 3).

The questionnaire was developed in French and English and translated into Lithuanian (see Figure 3). In addition, the content of the questionnaire has been validated [40]. Five pupils from each age group completed the questionnaire before the study. All words and their meanings were discussed with these children. Comments on the questionnaire were also elicited. All the children stated that they understood all the words and chose the answers as they did.

3.3. Data Analysis Method. The collected data were analysed using SPSS version 20. The data analysis used a descriptive 
Do you like school?

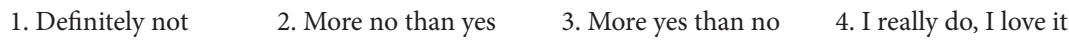

Figure 1: Example of a question on student attitudes towards school.

\begin{tabular}{lccc}
\hline & $\begin{array}{c}\text { You're } \\
\text { learning } \\
\text { successfully }\end{array}$ & $\begin{array}{c}\text { You're } \\
\text { learning on } \\
\text { average }\end{array}$ & $\begin{array}{c}\text { You have } \\
\text { difficulties }\end{array}$ \\
\hline Grade 1 (6-7 years), $\mathrm{N}=47$ & 16 & 27 & 4 \\
Grade 2 (7-8 years), $\mathrm{N}=51$ & 16 & 33 & 2 \\
Grade 3 (8-9 years), $\mathrm{N}=53$ & 19 & 32 & 2 \\
Grade 4 (9-10 years), $\mathrm{N}=35$ & 10 & 23 & 2 \\
\hline
\end{tabular}

Figure 2: Distribution of pupils' views on assessing learning achievements (significance level of $p=0.01$ ).

How do you work in a group? (Mark the box that works best with a cross + )

\begin{tabular}{l}
\hline Never \\
$\begin{array}{l}\text { From time to } \\
\text { time }\end{array}$ \\
You listen to others \\
You explain to others \\
You're bored \\
You take into account the ideas, the \\
opinions of others \\
You argue \\
You are interested \\
You're thinking about other things \\
You work \\
You're learning new things
\end{tabular}

Figure 3: Example of a question whose optional answers are based on an interval scale when examining a pupil's individual attitude and ability to work in a group.

approach, calculating the answers chosen by the pupils. Internal consistency reliability was used to assess the reliability of the scale using Cronbach's alpha. This paper presents the results of the study when Cronbach's alpha is greater than 0.70 and when the $p$ value is $<0.05[40,41]$.

The empirical study data analysis section of the article presents the number of answers selected by pupils according to each choice, which will allow seeing pupils' views and attitudes in different aspects of pupils' commitment to work in a group. A higher number chosen by respondents means more frequent use of a particular strategy.

All the questionnaires submitted to the pupils were in paper form, and the children marked the answers to the questions with their hands. The questionnaire was submitted in Lithuanian. Due to the limited scope of the article, an analysis of only part of the survey data is provided.

Study Sample: the study involved 186 pupils from a primary school in a big city in Lithuania. Provided below is pupils' division by their grade: grade 1 (6-7 years), 47 pupils; grade 2 (7-8 years), 51 pupils; grade 3 (8-9 years), 53 pupils; and grade 4 (9-10 years), 35 pupils.

\section{Results}

The study identified the proportion of pupils who liked school. This data is given in Figure 4.

From the data in Figure 4, we can see that pupils' attitudes towards the school are generally positive. First-grade pupils are most positive because only two children have pointed out that they do not like school. In summary, we can say that the school's microclimate is good because $90 \%$ of school students think they love school or like it more than they do not like it. The issue of attitudes to school could be further discussed with second-grade students, as nine children of this age chose the statement that they really do not like the school or do not like it more than they like it.

Students were also asked about how they valued their learning achievements.

From the data in Figure 5, we can see that most children see their learning as successful or average. A small proportion of students say they have difficulties. Pupils are likely to take an adequate view of their results. According to the value of the choices, we can argue that children are 


\begin{tabular}{lcccc}
\hline & $\begin{array}{c}\text { Definitely } \\
\text { not }\end{array}$ & $\begin{array}{c}\text { More no } \\
\text { than yes }\end{array}$ & $\begin{array}{c}\text { More yes } \\
\text { than no }\end{array}$ & $\begin{array}{c}\text { I really do, } \\
\text { I love it }\end{array}$ \\
\hline Grade 1 (6-7 years), $\mathrm{N}=47$ & 1 & 1 & 22 & 23 \\
Grade 2 (7-8 years), $\mathrm{N}=51$ & 5 & 4 & 21 & 21 \\
Grade 3 (8-9 years), $\mathrm{N}=53$ & 3 & 3 & 23 & 24 \\
Grade 4 (9-10 years), $\mathrm{N}=35$ & 1 & 3 & 22 & 9 \\
\hline
\end{tabular}

FIGURE 4: Distribution of pupils' opinion on whether they like school (significance level of $p=0.01$ ).

\begin{tabular}{lccc}
\hline Grade 3 (8-9 years), $\mathrm{N}=53$ & Never & $\begin{array}{c}\text { From time to } \\
\text { time }\end{array}$ & Frequently \\
\hline You listen to others & 1 & 23 & 29 \\
You explain to others & 4 & 32 & 17 \\
You're bored & 33 & 19 & 33 \\
$\begin{array}{l}\text { You take into account the ideas, the } \\
\text { opinions of others }\end{array}$ & 5 & 15 & 1 \\
You argue & 35 & 19 & 30 \\
You are interested & 2 & 21 & 9 \\
You're thinking about other things & 26 & 18 & 48 \\
You work & - & 5 & 38 \\
You're learning new things & 1 & 14 & 19 \\
\hline
\end{tabular}

FIGURE 5: Breakdown of opinions among pupils in grade 3 based on how they work in a group (significance level of $p=0.01$ ).

\begin{tabular}{lccc}
\hline Grade 1, (6-7 years old), $\mathrm{N}=47$ & Never & $\begin{array}{c}\text { From time to } \\
\text { time }\end{array}$ & Frequently \\
\hline You listen to others & 3 & 13 & 31 \\
You explain to others & 2 & 20 & 25 \\
You're bored & 38 & 4 & 5 \\
$\begin{array}{l}\text { You take into account the ideas, the } \\
\text { opinions of others }\end{array}$ & 17 & 10 & 20 \\
You argue & 37 & 9 & 1 \\
You are interested & 27 & 21 & 7 \\
You're thinking about other things & 2 & 13 & 40 \\
You work & 1 & 8 & 38 \\
\hline You're learning new things & & 5 & 7 \\
\hline
\end{tabular}

Figure 6: Breakdown of opinions among pupils in grade 1 based on how they work in a group (significance level of $p=0.01$ ).

motivated as well. It can also be seen that primary school children can objectively self-assess their learning, think about how often they do activities correctly, without errors, and when and what kind of help they need. Therefore, the most common answer was that they "learn on average."

The study also aimed at looking into how pupils in each grade were able to focus and work in a group, what roles they usually have, whether they develop language skills while learning to listen to others' opinions and share thoughts and experiences. For first-grade pupils (6-7 years), the breakdown of responses to the question "how children work in a group" is shown in Figure 6.

From the data in Figure 6, we can see that the majority of first-graders, in their opinion, are engaged in working in a group and can both listen and explain. It is also important that the majority of children have indicated that they are never bored but occasionally or frequently have an interest in group activities. Therefore, the work in the group is interesting. We can also see from the data that first-grade children still lack deeper cooperation abilities, as thirty 


\begin{tabular}{lccc}
\hline Grade 2 (7-8 years), $\mathrm{N}=51$ & Never & $\begin{array}{c}\text { From time to } \\
\text { time }\end{array}$ & Frequently \\
\hline You listen to others & 5 & 26 & 20 \\
You explain to others & 6 & 30 & 15 \\
You're bored & 26 & 15 & 10 \\
$\begin{array}{l}\text { You take into account the ideas, the } \\
\text { opinions of others }\end{array}$ & 9 & 25 & 17 \\
You argue & 75 & 13 & 3 \\
You are interested & 17 & 23 & 21 \\
You're thinking about other things & - & 24 & 43 \\
You work & 2 & 8 & 38 \\
\hline You're learning new things & & 11 & 40 \\
\hline
\end{tabular}

Figure 7: Breakdown of opinions among pupils in grade 1 based on how they work in a group (significance level of $p=0.01$ ).

children said that they often or occasionally take into account the ideas and opinions of others, but 17 children reported never doing so. This situation should therefore be discussed and explained in terms of the meaning and significance of taking account of the other's views, especially where each child should contribute to group activities. The fact that as many as 37 children chose the answer that they did not argue also shows that children are already skilled in working in a group and know how to reach an agreement. ,the children were deliberately and responsibly answering questions is also reflected in the answers to questions "about whether you are thinking about other things or whether you work." Most children have indicated that they never think about other things and often work. In addition, they often learn new things when they work in a group.

The same questions about "how children work in a group" were also given to second-grade students (6-7 years old). The breakdown of the answers of these pupils is shown in Figure 7.

From the data in Figure 7, we can see that most secondgrade pupils can listen to others and explain to others when they work in a group. This means that second-graders can already show incentive-based interaction when working in a group because they have already developed speaking and listening skills. In addition, most children reported the ability to take account of ideas and opinions of others, work together, and learn new things. These skills mean that pupils feel individual and mutual responsibility and accountability. In addition, the fact that more than half of the secondgraders (as many as 35 children) indicated that they did not argue reinforces their mutual responsibility and coworking skills. Children work in a motivated way, and this can be seen by analysing other answers, such as "whether you are bored, whether you are interested, whether you're thinking about other things while working in a group." The answers to these questions show that children think they can work in a team and are usually engaged in activities.

Figure 5 provides answers for class 3 students (8-9 years) to the same questions about working in a group.
From the data in Figure 7, we can see that third-graders see working in the group as a motivating activity because as many as 33 children have never been bored and as many as 48 children have often worked. Importantly, as many as 38 students chose an answer that they learn new things while working in a group. This means that group work is linked to the development of cognitive skills. The skills of working together are also reflected in the responses that the majority of children do not argue ( 35 children pointed out this). So they can reach an agreement. This is evidenced by the fact that most third-graders indicated that they sometimes or often listen to others while working in a group, explain to others, and are interested in activities.

Figure 8 shows how children in grade 4 (9-10 years) assess individual abilities of working in a group.

The choice of answers, with most fourth-grade pupils choosing "frequently," indicates that while learning in group, children are able to work, learn new things, be interested, and know how to listen to other opinions. Other indicators also show the quality of working in a group, such as "you're bored and you're thinking about other things." We can see that a lot of fourth-grade pupils do not do that when they work in a group. So they are motivated. However, based on these indicators, there is almost the same proportion of pupils saying they sometimes get bored or are thinking about other things. This result suggests that pupils may not be involved in the education process. They may be unattentive or find it harder to learn some things. It is worth looking into the reasons for pupils thinking about other things in the future. The quality of language skills is also demonstrated by the fact that when working in a group they often or sometimes explain to each other, as well as often or sometimes taking into account the ideas of others when making decisions.

\section{Discussion}

The majority of students in the study find that they are engaged in group work and can both listen and explain. 


\begin{tabular}{lccc}
\hline Grade 4 (9-10 years), N=35 & Never & $\begin{array}{c}\text { From time to } \\
\text { time }\end{array}$ & Frequently \\
\hline You listen to others & - & 10 & 25 \\
You explain to others & 2 & 26 & 7 \\
You're bored & 19 & 15 & 19 \\
$\begin{array}{l}\text { You take into account the ideas, the } \\
\text { opinions of others }\end{array}$ & 2 & 14 & 3 \\
You argue & 9 & 23 & 23 \\
You are interested & - & 12 & 2 \\
You're thinking about other things & - & 15 & 31 \\
You work & - & 4 & 26 \\
\hline You're learning new things & & 9 & \\
\hline
\end{tabular}

FIGURE 8: Breakdown of opinions among pupils in grade 4 based on how they work in a group (significance level of $p=0.01$ ).

Children find group work interesting as most of them reported that they are never bored and are occasionally or usually interested in group activities. These facts show that when group work is organised properly and systematically, its benefits and meaning in the context of learning are already seen by first-grade pupils. In addition, children learn subjects that are important for communication, such as listening to others, explaining to others, making decisions with taking ideas or opinions of others into consideration, or abandoning the proposed solution in a well-argued way [30-39]. These skills will be particularly needed in various life situations. In addition, many new things from different fields of science can be learned and acquired.

Most primary school pupils of all age's associate group work with learning new things, good communication skills, and being engaged in work. However, pupils in grade 2 indicated that they occasionally take other people's opinions into account and think about other things. This means that some pupils lack an understanding of how to work in a group. For this reason, it would be useful to differentiate the instructions for the activities and to explain to the pupils in more detail why they should listen to others' opinions and how to do this in a good way. These insights from the study are supported by the work of other researchers [42-47]. In addition, pupils' attitudes towards cooperative learning should be more closely linked to direct achievement, as lowachieving students are more in need of additional learning support [42]. For low-achieving pupils in the classroom, well-structured learning interventions are important [43]. However, differentiation of educational content is a complex process, although it helps to address equity issues [44] when it considers the child's individual needs and capabilities. Future research could organise activities to find out what roles children have had in cooperative learning and link their individual contributions directly to their responses to the questionnaire.

Primary school pupils associate group work activities with learning new things, that is, the cognitive domain and the possibility of learning. In this respect, the study's findings are in line with other researchers' insights that cooperative learning improves academic achievement [34-37]. We can say that being ready to apply the principles of cooperative learning at school on the entire community basis when children learn new things while working in groups or while generalising experience in areas they have already learned $[9,11,34-39]$, we can make great achievements in primary classes. Primary school children are capable and able to work together with others. In addition, they are capable of adequately appreciating group work activities and personal contributions, of indicating when and how they work, and the personal contribution they make to joint group work activities.

\section{Conclusions}

In primary school, pupils' motivation and academic achievements improve when they feel respected and safe, when they have a positive view of their teacher's performance, and when there is an atmosphere of mutual assistance and support in the classroom. Only in a positive environment can a culture of cooperative learning be developed, too. Children can then share their experiences and opinions, learn to listen to others' opinions and explain to others, and take into account the ideas of others when learning together. When an atmosphere of shared work skills is created, children can appreciate their abilities and, at the same time, recognise that they can work and learn new things in such conditions.

Analysis of the survey results showed that primary school pupils can adequately self-assess their ways of working in classes and understand their benefits, meaning, and significance when learning through cooperation. Most pupils indicated that they liked the school they attended and the activities they did during the education process. This is a very important indicator that allows pupils to have a positive attitude and achieve success through learning. In addition, children reported that they are most likely to be successful or average in their studies. 
Most first-to-fourth grade pupils indicated that they were able to work in a group and collaborate because they were willing to listen to others, explain to others, and help them if needed. In addition, most students are not bored when they work in a group, and they are interested in working together. Children rarely argue, often work together, and learn new things. There was a difference in pupils' attitude regarding taking others' ideas into account. Most fourth-grade pupils responded to the question that they always took into account the ideas and opinions of others, while more than a third of first-grade pupils indicated that they never took into account the views of their peers. We would think that this division of opinion is due to the age of pupils because in their early years, they are still egocentric, and they are struggling to be empathetic, to hear others, even though they already learn this from the first grade.

It should be noted that such results are obtained after half a year of working together in the community of teachers and pupils through the targeted and systematic application of cooperative learning strategies in lessons of all subjects.

\section{Implications, Future Perspectives, and Limitations}

The study described in this paper sheds light on the attitudes of primary school pupils in one school towards the linguistic aspects of cooperative learning. Importantly, pupils realise that, by working together, they can explain to each other what they are learning; they learn to take into account each other's opinions and ideas; and they are interested in what they are doing during the educational process. These are integral linguistic skills that children can develop in a variety of subjects. The cooperative learning approach is conducive to this process because it allows pupils to discuss and debate. As the implementation of the methodology was adopted universally in the school, with all teachers using the cooperative learning methodology in different lessons, the study's findings are significant as they show that educational practices can be changed by working innovatively within the educational community. In such cases, the pupils also feel and understand this. The study shows that both firstand fourth-grade pupils think similarly about cooperative learning. In the interest of active learner practice, the findings of this study are of relevance for university lecturers training primary school teachers, education policymakers, and innovative teacher practitioners. They will also allow researchers in other countries to conduct similar research and compare the results with our study.

\section{Data Availability}

Survey data were collected through questionnaires.

\section{Conflicts of Interest}

The author declares no conflicts of interest.

\section{Acknowledgments}

The study analysed in the article was carried out as part of the Erasmus+ strategic partnerships project "Inclusive Cooperation in the Education System" (DICO+ 2019-2021, Nr. 2018-1-FR01-KA201-047904). The context of cooperative learning and the attitudes of primary school pupils have been studied in France, The Netherlands, Italy, Spain, Hungary, Romania, and Lithuania. The article contains the data of the Lithuanian investigation. It discusses the results of the questionnaire survey of all the students engaged in cooperative learning activities, which were included at the school during a period of six months.

\section{References}

[1] Good School Concept, Approved by Order No V-1308 of 21 December 2015 of the Minister of Education and Science of the Republic of Lithuania, Lithuanian Ministry of Education and Science, Vilnius, Lithuania, 2015.

[2] NEA, Draft of the Lithuanian Language Framework Programmes, National Education Agency, Vilnius, Lithuania, 2021, https:/www.mokykla2030.lt/kalbinis-ugdymas-2/.

[3] Council of Europe, Common European Framework of Reference for Languages: Learning, Teaching, Assessment, Council of Europe, Strasbourg, France, 2018.

[4] M. Candelier, Evlang - l'éveil aux langues à l'école primaire-Bilan d'une innovation européenne (Evlang - awakening to languages in primary school-Review of a European innovation), De Boek-Duculot, Bruxelles, Belgium, 2003.

[5] M. Candelier, "Awakening to languages and language policy," in Encyclopedia of Language and Education, J. Cenoz and N. Hornberger, Eds., vol. 6, pp. 219-232, Springer, Heidelberg, Germany, 2007.

[6] C. Goï, Des élèves venus d'ailleurs (Students From Elsewhere), Scéren-CNDP, Orléans, France, 2005.

[7] C. Goï, Diversité, pluralité, hétérogénéité: quelles recherches qualitatives en sciences humaines? (Diversity, plurality, heterogeneity: what qualitative research in the human sciences?), L'Harmattan, Paris, France, 2012.

[8] C. Goï and E. Huver, Des enseignants aux chercheurs en didactique des langues. Postures épistémologiques entre identités, cultures et imaginaires Professionnels. (From teachers to researchers in language teaching. Epistemological postures between identities, cultures and imaginaries Professionals). Les didactiques au prisme de l'épistémologie, Presses universitaires de Dijon, Dijon, France, 2013.

[9] J. C. Torrego-Seijo, P. A. Caballero-García, and E. M. Lorenzo-Llamas, "The effects of cooperative learning on trait emotional intelligence and academic achievement of Spanish primary school students," Educational Psychology, vol. 91, no. 3, pp. 928-949, 2020.

[10] R. Meganingtyas, B. R. Winarni, and T. Murwaningsih, "The implementation of cooperative learning at primary schools," in Proceedings of the 1st International Conference on Life, Innovation, Change and Knowledge (ICLICK 2018), July 2019.

[11] N. Klang, I. Olsson, J. Wilder, G. Lindqvist, N. Fohlin, and C. Nilholm, "A cooperative learning intervention to promote social inclusion in heterogeneous classrooms," Frontiers in Psychology, vol. 11, Article ID 586489, 2020.

[12] UNESCO, A Guide for Ensuring Inclusion and Equity in Education, UNESCO, Paris, France, 2017. 
[13] F. Lasnier, "Un modèle intégré pour l'apprentissage d'une compétence (//an integrated model for learning a skill)," Pédagogie collégiale.vol. 15/1, pp. 28-33, 2001.

[14] P. Meirieu, L'éducation et le rôle des enseignants à l'horizon 2020 (//Education and the role of teachers towards 2020), UNESCO, Paris, France, 2006.

[15] N. Rousseau, Les enjeux de l'intégration et de l'inclusion scolaire des élèves à risque du primaire et du secondaire: métaanalyse et méta synthèse. (The Challenges of school integration and inclusion of at-risk elementary and secondary school students: meta-analysis and metasynthesis). Rapport de recherché $n^{\circ}$ 2014-AP-179083, Université du Québec à TroisRivières, Québec, Canada, 2015.

[16] A. Florin and P. Guimard, La qualité de vie à l'école. (The Quality of Life at School), Cnesco, Paris, France, 2017.

[17] C.-K. Kong, "Classroom learning experiences and students' perceptions of quality of school life," Learning Environments Research, vol. 11, no. 2, pp. 111-129, 2008.

[18] W. Liu, L. Tian, E. Scott Huebner, X. Zheng, and Z. Li, "Preliminary development of the elementary school students' subjective well-being in school scale," Social Indicators Research, vol. 120, no. 3, pp. 917-937, 2014.

[19] J. J. Randolph, M. Kangas, and H. Ruokamo, "Predictors of Dutch and Finnish children's satisfaction with schooling," Journal of Happiness Studies, vol. 11, no. 2, pp. 193-204, 2010.

[20] J. A. Baker, L. J. Dilly, J. L. Aupperlee, and S. A. Patil, "The developmental context of school satisfaction: schools as psychologically healthy environments," School Psychology Quarterly, vol. 18, no. 2, pp. 206-221, 2003.

[21] L. M. Gutman and L. Feinstein, Children's Well-Being in Primary School: Pupil and School Effects, Centre for Research on the Wider Benefits of Learning Institute of Education, London, UK, 2008.

[22] B. Guimard and F. Ferrière, Evaluation du bien-être perçu des élèves: étude longitudinale à l'école élémentaire et au collège. Recherche complémentaire (BE-Scol2). (Assessment of perceived student well-being: longitudinal study in elementary school and college. Further research). Rapport pour la Direction de l'évaluation de la prospective et de la performance. Convention 2015DEPP-028, 2017.

[23] D. W. Johnson and R. T. Johnson, "Cooperative learning and achievement," in Cooperative Learning: Theory and Research, S. Sharan, Ed., pp. 23-37, Praeger, New York, NY, USA, 1990.

[24] D. W. Johnson and R. T. Johnson, Learning Together and Alone: Cooperative, Competitive, and Individualistic Learning, Allyn \& Bacon, Boston, MA, USA, 1999.

[25] D. W. Johnson and R. T. Johnson, "Social interdependence theory and cooperative learning," in The Teacher's Role, R. M. Gillies, A. F. Ashman, and J. Terwel, Eds., Springer, Berlin, Germany, 2008.

[26] D. W. Johnson and R. T. Johnson, "Student motivation in cooperative groups: social interdependence theory," in Cooperative Learning: The Social and Intellectual Outcomes of Learning in Groups, R. Gillies and A. Ashman, Eds., pp. 136-176, Routledge Falmer, London, UK, 2003.

[27] C. Buchs, Comment Organiser l'apprentissage des élèves par petits groupes? (How to Organize Student Learning in Small Groups?) In: Différenciation pédagogique: comment adapter l'enseignement pour la réussite de tous les élèves?, Conseil National d'évaluation du Système Scolaire, Paris, France, 2017, https://archive-ouverte.unige.ch/unige:95551.

[28] C. Buchs, V. Wiederkehr, D. Filippou, N. Sommet, and C. Darnon, "Structured cooperative learning as a means for improving average achievers' mathematical learning in fractions," Inovacije u nastavi, vol. 28, no. 3, pp. 15-35, 2015.

[29] C. Buchs and F. Butera, "Cooperative learning and social skills development," in Collaborative Learning: Developments in Research and Practice, R. Gillies, Ed., pp. 201-217, Nova Science, New York, NY, USA, 2015.

[30] R. M. Gillies, "The effects of cooperative learning on junior high school students during small group learning," Learning and Instruction, vol. 14, no. 2, pp. 197-213, 2004.

[31] R. M. Gillies, "The effects of cooperative learning on junior high school students' behaviours, discourse and learning during a science-based learning activity," School Psychology International, vol. 29, no. 3, pp. 328-347, 2008.

[32] R. Gillies, "Cooperative learning: review of research and practice," Australian Journal of Teacher Education, vol. 41, no. 3, pp. 39-54, 2016.

[33] R. M. Gillies, "Dialogic teaching during cooperative inquirybased science: a case study of a year 6 classroom," Education Sciences, vol. 10, no. 11, p. 328, 2020.

[34] E. Molla and M. Muche, "Impact of cooperative learning approaches on students' academic achievement and laboratory proficiency in biology subject in selected rural schools, Ethiopia," Educational Research International, vol. 2018, Article ID 6202484, 9 pages, 2018.

[35] S. Yaduvanshi and S. Singh, "Fostering achievement of low-, average-, and high-achievers students in biology through structured cooperative learning (STAD method)," Educational Research International, vol. 2019, Article ID 1462179, 10 pages, 2019.

[36] C. Buchs, "Apprendre ensemble: des pistes pour structurer les interactions en classe (learning together: ways to structure classroom interactions)," in Les interactions sociales en classe: réflexions et perspectives, M. Giglio and F. Arcidiacono, Eds., Peter Lang, Berne, Switzerland, 2017.

[37] E. de la Barra and S. Carbone, "Bridging inequality: cooperative learning through literature in two vulnerable schools in Santiago," Profile-Issues in Teachers' Professional Development, vol. 22, no. 2, pp. 49-63, 2020.

[38] C. Buchs, A. Dumesnil, J. Chanal, and F. Butera, "Dual effects of partner's competence: resource interdependence in cooperative learning at elementary school," Education Sciences, vol. 11, no. 5, p. 210, 2021.

[39] C. Buchs, D. Filippou, and C. Pulfrey, "Reducing threat in cooperative learning: the role of decentering," International Review of Social Psychology, vol. 31, pp. 1-7, 2018.

[40] V. Dikčius, Anketos Sudarymo Principai (Principles of Questionnaire design), Vilnius University, Vilnius, Lithuania, 2011.

[41] V. Pakalniškienè, Tyrimo ir ịvertinimo priemoniu patikimumo ir validumo nustatymas (Establishing the reliability and validity of the Study and Assessment Tools), Vilnius University, Vilnius, Lithuania, 2012.

[42] J. M. Faber, C. A. W. Glas, and A. J. Visscher, "Differentiated instruction in a data-based decision-making context," School Effectiveness and School Improvement, vol. 29, no. 1, pp. 43-63, 2018.

[43] A. Capodieci, T. Rivetti, and C. Cornoldi, "A cooperative learning classroom intervention for increasing peer's acceptance of children with ADHD," Journal of Attention Disorders, vol. 23, no. 3, pp. 282-292, 2019.

[44] L. J. Graham, K. De Bruin, C. Lassig, and I. Spandagou, "A scoping review of 20 years of research on differentiation: investigating conceptualisation, characteristics, and methods used," The Review of Education, vol. 9, no. 1, pp. 161-198, 2021. 
[45] T. H. S. Eysink and K. Schildkamp, "A conceptual framework for Assessment-Informed Differentiation (AID) in the classroom," Educational Research, vol. 63, no. 3, pp. 261-278, 2021.

[46] M. A. Veldman, S. Doolaard, R. J. Bosker, and T. A. B. Snijders, "Young children working together. Cooperative learning effects on group work of children in Grade 1 of primary education," Learning and Instruction, vol. 67, Article ID 101308, 2020.

[47] D. Cañabate, R. Bubnys, L. Nogué, L. Martínez-Mínguez, C. Nieva, and J. Colomer, "Cooperative learning to reduce inequalities: instructional approaches and dimensions," Sustainability, vol. 13, Article ID 10234, 2021. 